\title{
In vivo micronucleus test of 4-butylaniline and $N$-butylaniline to classify a chemical's mutagenicity according to the globally harmonized system of classification and labelling of chemicals (GHS)
}

\author{
Soo-Jin Kim ${ }^{1} \cdot$ Seo-ho Shin $^{1} \cdot$ Hyun-ock Kim ${ }^{1} \cdot$ Kyung-Taek Rim $^{1}$ \\ Received: 9 August 2019 / Accepted: 11 October 2019 / Published Online: 31 December 2019 \\ (C) The Korean Society for Applied Biological Chemistry 2019
}

\begin{abstract}
In vivo micronucleus tests were performed to investigate the mutagenic potential of 4-butylaniline and $N$-butylaniline, which are used in dye intermediates and organic intermediates respectively. Groups of 5 male ICR mice were treated with vehicle or 4-butylaniline for 2 consecutive days by oral gavage at concentrations of 0 (control), 64, 160, 400, and $1000 \mathrm{mg} / \mathrm{kg}$. Statistically significant and dose-dependent increases were found for micronuclei frequencies in male mice $(p<0.05)$. These results suggest that 4-butylaniline can induce genetic effects in the micronuclei of male mouse bone marrow cells. Based on the positive results obtained in cytogenetic analyses of somatic cells in vivo, Globally Harmonized System of Classification and Labelling of Chemicals Category 2 was assigned. $N$-butylaniline was administered for 2 consecutive days by oral gavage to male ICR mice at dose of 0 (control), 64, 160, 400, and $800 \mathrm{mg} / \mathrm{kg}$. $\mathrm{N}$ butylaniline tested negative for micronuclei induction in mice, although $N$-butylaniline was associated with micronucleus induction at the highest dose. Based on the negative results obtained for cytogenetic analyses of somatic cells in vivo, "Not Classified" was assigned.
\end{abstract}

Keywords 4-butylaniline $\cdot$ Genotoxicity $\cdot$ Micronucleus assay $\mathrm{N}$-butylaniline

Kyung-Taek Rim $(\triangle)$

E-mail:rim3249@gmail.com

${ }^{1}$ Chemicals Research Bureau, Occupational Safety and Health Research Institute, Korea Occupational Safety and Health Agency, 30, Expo-ro 339beon-gil, Yuseong-gu, Daejeon 34122, Republic of Korea

This is an Open Access article distributed under the terms of the Creative Commons Attribution Non-Commercial License (http://creativecommons. org/licenses/by-nc/3.0/) which permits unrestricted non-commercial use, distribution, and reproduction in any medium, provided the original work is properly cited.

\section{Introduction}

More than 15 million chemicals are commercially available worldwide. Approximately 60,000 to 70,000 chemicals are used regularly in everyday life, and 200 to 1,000 chemicals are produced every year in volumes exceeding 1 ton. The number and usage of chemical substances has rapidly increased with industrial advances in modern societies, such that 43,000 or more chemical substances are now circulating in Korea. Although more than 20,000 chemicals are circulating around the world, the hazards associated with these chemicals have not all been identified [1]. Since 2005, we have performed toxicology testing to assess the human health hazards of industrial chemicals. Our mission is to provide information on dangerous substances, prevent health hazards caused by exposure, assess potential hazards of chemicals, and improve the health of workers [2]. 4-Butylaniline is used in intermediates of dyes and pigments. $N$-is used in organic intermediates and is also used to make dyes. These substances are listed in both the TSCA (Toxic Substances Control Act) chemical substance inventory of the US EPA (United States Environmental Protection Agency) and the Annex III inventory of ECHA (European Chemicals Agency). Computer-aided (in silico) approaches were performed using QSAR Toolbox version 4.2, which is available on the OECD website (http://www.qsartoolbox.org/) $[3,4]$. 4-Butylaniline tested positive for prediction of gene mutation and carcinogenicity in read-across analyses. $\mathrm{N}$ butylaniline tested negative for prediction of gene mutation and positive for prediction of carcinogenicity in read-across analyses. In the Derek Nexus (version 6.0.1) program, both 4-butylaniline and $N$-butylaniline tested negative for prediction. A literature review provided no data other than acute toxicity data and no genotoxic data. Therefore, in 2017, our group performed bacterial mutagenicity tests ("Ames test") on two substances and determined that 4-butylaniline and $\mathrm{N}$-butylaniline were DNA-reactive genotoxic (positive) chemicals with no safe thresholds [5]. The Globally 
Harmonized System of Classification and Labelling of Chemicals (GHS) was developed to synchronize chemical regulations and standards in the United Nations. In addition to providing material safety data sheets and other information that should be included on the labelling of hazardous chemicals, the GHS includes criteria for physical hazards, health hazards, and environmental hazards [6]. GHS classification criteria for germ cell mutagens have been catalogued from around the world and have become the standard for classifying the hazards associated with chemical substances [7]. In the battery of genotoxicity tests available, rodent micronucleus assays are primarily used and recommended by regulatory agencies worldwide to assess chemical mutagenicity. When performed appropriately, this assay screens both clastogen and aneugen [8]. In in vivo micronucleus assays, cytogenetic assays detect not only DNA damage but also genetic toxicity by other mechanisms, such as topoisomerase inhibition, spindle poison, or excessive cytotoxicity. The objective of the present study is to demonstrate genotoxicity of 4-butylaniline and $\mathrm{N}$-butylaniline in vivo using micronucleus tests.

\section{Materials and Methods}

\section{Chemicals and reagents}

4-Butylaniline (CAS No. 104-13-2) was purchased from SigmaAldrich (94300, St Louis, MO, USA, Lot No. MKBS5221V). Mitomycin $\mathrm{C}$ was used as the positive control chemical and was purchased from Sigma-Aldrich (Lot No. SLBV1185). Olive oil was used as the vehicle or negative control chemical in the oral gavage given to the mice and was purchased from Sigma-Aldrich (Lot No. BCBW5235). N-butylaniline (CAS No. 1126-78-9) was purchased from Tokyo Chemical Industry Co., Ltd. (Tokyo, Japan, Lot No. WAQLC) (Table 1).

\section{Animals}

Seven-week-old male ICR (Institute for Cancer Research in

Table 1 Chemical Properties of 4-butlaniline and $N$-butylaniline

\begin{tabular}{lcc}
\hline \hline \multicolumn{1}{c}{ Items } & 4-Butylaniline Data & $N$-butylaniline Data \\
\hline CAS registry number & $104-13-2$ & $1126-78-9$ \\
Molecular weight & 149.23 & 149.23 \\
Structural formula & $\mathrm{C}_{10} \mathrm{H}_{15} \mathrm{~N}$ & $\mathrm{C}_{10} \mathrm{H}_{15} \mathrm{~N}$ \\
Appearance & Orange-colored liquid & Yellow or \\
orange-colored liquid \\
Boiling point & $133-134{ }^{\circ} \mathrm{C}$ & $240{ }^{\circ} \mathrm{C}$ \\
Water solubility & Soluble & Insoluble \\
Vapor density & N. A. & N. A. \\
Vapor pressure & N. A. & N. A. \\
$\begin{array}{l}\text { Partition coefficient } \\
\text { (Log } K_{\text {ow }}\end{array}$ & N. A. & N. A. \\
$\begin{array}{l}\text { Occupational exposure } \\
\text { levels (8-h TWA) }\end{array}$ & 2 ppm & N. A. \\
\hline
\end{tabular}

Philadelphia) mice were purchased from Japan SLC, Inc. (Hamamatsu, Shizuoka, Japan). After acclimation for one week, eight-week-old mice were used in the study. Food (a commercial diet Teklad Certified Irradiated Global 18\% Protein Rodent Diet 2918C, ENVIGO RMS Inc., Indianapolis, IN, USA) and water were given to mice ad libitum. The mice were housed in polysulfone cages (five individuals per cage) under controlled environmental conditions (temperature, $22 \pm 3{ }^{\circ} \mathrm{C}$; humidity, $50 \pm 20 \%$; lights on from 08:00 to 20:00 h). Mice body weights (b.w.) were monitored and recorded before treatment (day 1) and on days 2 and 3. Male ICR mice were exposed to 4-butylaniline $(0,64,160,400$, and $1000 \mathrm{mg} / \mathrm{kg}$ b.w.) and $N$-butylaniline $(0,64$, 160,400 , and $800 \mathrm{mg} / \mathrm{kg}$ b.w.) by oral gavage, respectively. Five control mice were gavaged with vehicle control (olive oil) in the same manner. Five male ICR mice were exposed to $0.5 \mathrm{mg} / \mathrm{kg}$ b.w. mitomycin $\mathrm{C}$ by i.p. injection for the positive control. The mice exposed to 4-butylaniline and $N$-butylaniline were studied the first and second days after substances exposure $(n=5$ at each time point). After acute single exposure to 4-butylaniline and $\mathrm{N}$ butylaniline, bone marrow cells were collected for micronucleus assay on days 1 and 2. The animal study protocol was reviewed and approved by the Institutional Animal Care and Use Committee/Animal Ethic Committee (IACUC/AEC) of the Occupational Safety and Health Research Institute (Approval No: IACUC1821 and IACUC1822).

\section{Micronucleus assay}

Micronucleus assays were performed as described in our previous report [9] and according to OECD Guideline 474 [10].

Twenty-four hours after the last administration for each time point, mice were euthanized by cervical dislocation, and bonemarrow cells from the right femurs were ushed out with $1 \mathrm{~mL}$ of fetal bovine serum (FBS, Cyclone, GE Healthcare, Chicago, IL, USA). After centrifuging for $5 \mathrm{~min}$ at $220 \times$ g, cell pellets were resuspended with the remaining serum and spread on clean glass slides. The slides were then air-dried overnight, xed with methanol for $5 \mathrm{~min}$, and stained with acridine orange $(40 \mu \mathrm{g} / \mathrm{mL} \mathrm{w} / \mathrm{v}$ in Sorensen buffer, $\mathrm{pH}$ 6.8). The number of micronucleated cells was recorded in each of 4,000 polychromatic erythrocytes (PCE) per animal using a uorescence microscope (Leica, DMLB, Wetzlar, Germany). Both individual group comparisons and dose-response trends were evaluated to conrm the positive results of the micronucleus tests. A statistically signicant increase in the micronucleated polychromatic erythrocyte (MNPCE) frequency at any individual concentration (compared to that of the control) or a dosedependent increase was considered a positive result.

\section{Statistical analysis}

Micronucleus assay data were expressed as means \pm SD. Statistical analyses were performed using SigmaPlot for Windows Version 11.0 (SyStat Software, Inc., San Jose, CA, USA). Comparisons between two groups were assessed using Student's $t$-tests, and 
values of $p<0.05$ were considered statistically significant.

\section{Results}

\section{4-Butylaniline, Cat. 2}

Four mice demonstrated decreased locomotor activities after 4butylalanine treatments with $400 \mathrm{mg} / \mathrm{kg}$ b.w. on day 1. Decreased locomotor activity was observed in five mice after 4-butylalanine treatments with $400 \mathrm{mg} / \mathrm{kg}$ b.w. on day 2. Decreased locomotor activity was observed in four mice after 4-butylalanine treatments with $400 \mathrm{mg} / \mathrm{kg}$ b.w. on day 3 . Decreased locomotor activity was observed in five mice after 4-butylalanine treatments with 1,000 $\mathrm{mg} / \mathrm{kg}$ b.w. on day 1 . Decreased locomotor activity was observed in three mice after 4-butylalanine treatments with $1,000 \mathrm{mg} / \mathrm{kg}$ b.w. on day 2 . In one case on day 1 and in three cases on day 2 , $1,000 \mathrm{mg} / \mathrm{kg}$ b.w. of 4-butylalanine was observed to cause debilitating behavior. Decreases in body weight were evident on day 3 after dosing at $400 \mathrm{mg} / \mathrm{kg}$ b.w. Decreased body weights were also observed on day 2 after dosing at $1,000 \mathrm{mg} / \mathrm{kg}$ b.w. (Table 2). Three of the five mice treated with $1,000 \mathrm{mg} / \mathrm{kg}$ b.w. died on day 2 after dosing. Two of the two mice treated with 1,000 $\mathrm{mg} / \mathrm{kg}$ b.w. died on day 3 after dosing. Statistically significant increases in micronuclei frequencies were observed when $400 \mathrm{mg} /$ kg b.w. ( $p<0.05$; Table 3) was administered, indicating positive rodent micronucleus test results. No changes were observed in the polychromatic/mature erythrocytes ratios obtained for the animals treated with 4-butylaniline and negative controls. Positive results

Table 2 Body weight of animals

\begin{tabular}{lccc}
\hline \hline \multirow{2}{*}{ Groups } & \multicolumn{3}{c}{ Body weight (g) at the time of } \\
\cline { 2 - 4 } & \multicolumn{2}{c}{ Administration } & \multirow{2}{*}{ Termination } \\
\cline { 2 - 4 } & $35.34 \pm 1.62$ & $35.83 \pm 1.30$ & $36.11 \pm 2.04$ \\
\hline Negative control & $37.18 \pm 1.83$ & $37.49 \pm 2.06$ & $38.01 \pm 2.10$ \\
4-Butylaniline $64 \mathrm{mg} / \mathrm{kg}$ & $36.49 \pm 1.56$ & $36.74 \pm 1.10$ & $36.94 \pm 0.97$ \\
4-Butylaniline $160 \mathrm{mg} / \mathrm{kg}$ & $36.87 \pm 1.53$ & $36.48 \pm 2.06$ & $34.49 \pm 2.05$ \\
4-Butylaniline $400 \mathrm{mg} / \mathrm{kg}$ & $37.45 \pm 2.20$ & $35.39 \pm 2.74$ & $\mathrm{~N} . \mathrm{A}$. \\
4-Butylaniline $1000 \mathrm{mg} / \mathrm{kg}$ & $37.70 \pm 2.48$ & $38.34 \pm 2.63$ & $38.61 \pm 2.36$ \\
Mitomycin C $0.5 \mathrm{mg} / \mathrm{kg}$ & 3 & & \\
\hline
\end{tabular}

Table 3 MNPCE frequencies among total erythrocytes induced by acute single exposure to 4-butylaniline in male mice

\begin{tabular}{lccc}
\hline \hline Treatment & Mice & $\begin{array}{c}\text { Immature Erythrocyte } \\
\text { Frequency (\%) }\end{array}$ & $\begin{array}{c}\text { Micronuclei } \\
\text { Frequency (\%) }\end{array}$ \\
\hline $0(\mathrm{NC})$ & 5 & $52.04 \pm 6.92$ & $0.16 \pm 0.06$ \\
$64 \mathrm{mg} / \mathrm{kg}$ & 5 & $49.52 \pm 10.56$ & $0.21 \pm 0.05$ \\
$160 \mathrm{mg} / \mathrm{kg}$ & 5 & $51.52 \pm 8.92$ & $0.38 \pm 0.12$ \\
$400 \mathrm{mg} / \mathrm{kg}$ & 5 & $55.60 \pm 20.08$ & $1.35 \pm 0.64^{*}$ \\
$\mathrm{PC}$ & 5 & $52.76 \pm 7.81$ & $1.16 \pm 0.19^{*}$ \\
\hline
\end{tabular}

Data are presented as mean frequencies $\pm \mathrm{SD}(\mathrm{n}=5 /$ group $)$

$* p<0.05$ compared to 0 (NC)
Table 4 Body weight of animals

\begin{tabular}{lccc}
\hline \multirow{2}{*}{\multicolumn{1}{c}{ Groups }} & \multicolumn{3}{c}{ Body weight (g) at the time of } \\
\cline { 2 - 4 } & \multicolumn{2}{c}{ Administration } & Termination \\
\cline { 2 - 4 } & $36.89 \pm 1.01$ & $37.61 \pm 1.33$ & $38.26 \pm 1.13$ \\
\hline Negative control & $36.80 \pm 1.22$ & $37.20 \pm 1.17$ & $37.17 \pm 1.82$ \\
$N$-butylaniline $64 \mathrm{mg} / \mathrm{kg}$ & $36.78 \pm 0.68$ & $37.51 \pm 0.50$ & $37.83 \pm 0.60$ \\
$N$-butylaniline $160 \mathrm{mg} / \mathrm{kg}$ & $37.56 \pm 1.23$ & $37.48 \pm 1.66$ & $35.41 \pm 2.87$ \\
$N$-butylaniline $400 \mathrm{mg} / \mathrm{kg}$ & $36.79 \pm 1.22$ & $35.87 \pm 1.40$ & $34.02 \pm \mathrm{N}$. A. \\
$N$-butylaniline $800 \mathrm{mg} / \mathrm{kg}$ & $37.30 \pm 1.06$ & $37.93 \pm 0.96$ & $37.77 \pm 1.68$ \\
Mitomycin C $0.5 \mathrm{mg} / \mathrm{kg}$ & 3 & & \\
\hline
\end{tabular}

Table 5 MNPCE frequencies among total erythrocytes induced by acute single exposure to $N$-butylaniline in male mice

\begin{tabular}{lccc}
\hline \hline Treatment & Mice & $\begin{array}{c}\text { Immature Erythrocyte } \\
\text { Frequency (\%) }\end{array}$ & $\begin{array}{c}\text { Micronuclei } \\
\text { Frequency (\%) }\end{array}$ \\
\hline $0(\mathrm{NC})$ & 5 & $61.68 \pm 4.22$ & $0.21 \pm 0.05$ \\
$64 \mathrm{mg} / \mathrm{kg}$ & 5 & $59.00 \pm 6.90$ & $0.21 \pm 0.01$ \\
$160 \mathrm{mg} / \mathrm{kg}$ & 5 & $53.80 \pm 6.80$ & $0.23 \pm 0.06$ \\
$400 \mathrm{mg} / \mathrm{kg}$ & 4 & $49.28 \pm 2.91^{*}$ & $0.19 \pm 0.04$ \\
$800 \mathrm{mg} / \mathrm{kg}$ & 1 & $51.80 \pm 0.00$ & $0.45 \pm 0.00$ \\
PC & 5 & $50.08 \pm 6.86$ & $1.12 \pm 0.34$ \\
\hline
\end{tabular}

Data are presented as mean frequencies \pm SD $(n=5 /$ group $)$

$* p<0.05$ compared to 0 (NC)

were obtained from bacterial mutagenicity tests in a previous study. Based on the positive results obtained for cytogenetic analyses in somatic cells in vivo, GHS Category 2 was assigned.

\section{$N$-butylaniline, Not Classified}

Decreased locomotor activity was observed in all subjects after treatment with 400 and $800 \mathrm{mg} / \mathrm{kg}$ b.w. on day 1. Decreased locomotor activity was observed in all (5/5) subjects after treatment with $400 \mathrm{mg} / \mathrm{kg}$ b.w. on day 2. Decreased locomotor activity was observed in three mice after treatment with $800 \mathrm{mg} /$ $\mathrm{kg}$ b.w. on day 2. Decreased locomotor activity was observed in one mouse after treatment with 400 and $800 \mathrm{mg} / \mathrm{kg}$ b.w. on day 3, respectively. In the group that received $800 \mathrm{mg} / \mathrm{kg}$ b.w., debilitation was determined in three cases on day 2 and one case on day 3. One of the five mice treated with $400 \mathrm{mg} / \mathrm{kg}$ b.w. died on day 3 after dosing. Decreases in body weight were evident on day 3 after dosing at $400 \mathrm{mg} / \mathrm{kg}$ b.w. Decreases in body weight were evident on day 2 and day 3 after dosing at $800 \mathrm{mg} / \mathrm{kg}$ b.w. (Table 4). Two of the five mice treated with $800 \mathrm{mg} / \mathrm{kg}$ b.w. died on day 2 after dosing, and two of the three mice treated with $800 \mathrm{mg} / \mathrm{kg}$ b.w. died on day 3 after dosing. Rodent micronucleus test results were negative. Significant changes were observed in the polychromatic/ mature erythrocytes ratios among the animals treated with 400 $\mathrm{mg} / \mathrm{kg}$ b.w. $N$-butylaniline (Table 5 ). Positive bacterial mutagenicity test results were obtained in a previous study. Based on the negative results obtained for cytogenetic analyses in somatic cells in vivo, "Not Classified (NC)" was assigned. 


\section{Discussion}

Evaluation of micronucleus induction in vivo is the essential part of genotoxicity tests and is recommended by the regulatory agencies to be conducted as part of chemical risk assessment [11]. Under the Occupational Safety and Health Act, a person who intends to manufacture or import a new chemical should submit a report investigating the harmfulness or danger of the new chemical in Korea [12]. In addition, according to the Act on Registration, Evaluation, etc. of Chemicals, those who manufacture and import chemicals at least ten tons per year subject to registration should prepare and submit data for hazard review and risk assessment in Korea [13]. Micronucleus assays data using test animals correspond to mutagenicity data for human health in these reports. The micronucleus assay detects both clastogenicity (chromosome breakage) and aneugenicity (chromosome lagging due to mitotic spindle dysfunction) and is designed primarily for evaluating the ability of test agents to induce structural and/or numerical chromosomal damage. Both kinds of damage are associated with the appearance and/or progression of tumors, and with adverse reproductive and developmental effects [14]. The aromatic amine, 4-butyl-aniline, is a proven and potent agent that short circuits the chromophore visual cycle in the intact mammalian retina/retinal pigment epithelium (RPE) by preventing new synthesis of 11-cis-retinal either from Vitamin A or from all-transretinal that results from rhodopsin bleaching [15]. In liver microsomal preparations, the para-hydroxylation of $\mathrm{N}$-butylaniline was shown to be stimulated by acetone [16]. The objective of this study was to investigate whether 4-butylaniline and $N$-butylaniline caused induction of micronuclei in the in vivo micronucleus test. The UN GHS classifies 4-butylaniline as Category 3 for acute toxicity and Category 2 for eye and skin irritation. The UN GHS classifies $N$-butylaniline as Category 4 for acute toxicity and Category 2 for eye and skin irritation. The LD50 value reported for mouse intraperitoneal acute toxicity for 4-butylaniline is 81 $\mathrm{mg} / \mathrm{kg}$ [17]. In the present study, the oral LD50 was greater than $800 \mathrm{mg} / \mathrm{kg}$ in mice. Five male mice in the $1,000 \mathrm{mg} / \mathrm{kg}$ group died. In the ICR mice administered $400 \mathrm{mg} / \mathrm{kg}$ 4-butylaniline (oral) in the present study, increases in micronucleated polychromatic erythrocytes (PCEs) were observed relative to concurrent control values. The $\mathrm{PCE} / \mathrm{PCE}+\mathrm{NCE}$ ratios in control and treated groups were compared and no significant changes were observed. The LD50 value reported for rat oral acute toxicity for $\mathrm{N}$--butylaniline is $1,620 \mathrm{mg} / \mathrm{kg}$ [18]. In the present study, the oral LD50 was greater than $800 \mathrm{mg} / \mathrm{kg}$ in mice, four of the five male mice in the $800 \mathrm{mg} / \mathrm{kg}$ group died, and no increments of incidence of micronucleated polychromatic erythrocytes (MNPCEs) were observed relative to the negative control group. When comparing control and treated groups, statistically significant decreases were found in ratios of PCE to total erythrocytes. A statistically significant reduction in the ratio of PCEs compared with the negative control indicates bone marrow toxicity (i.e., inhibition of cell proliferation). In the present study, mitomycin $\mathrm{C}$ used as a positive control, and it showed a significant increases of MNPCE ratios. This indicates that the experimental design and the results of the present study are acceptable [19]. The sensitivity, specificity and concordances of the Ames test are known to be 58.8, 73.9 or $62.5 \%$, respectively [20]. The sensitivity, specificity or concordances of the in vivo micronucleus assay are known to be 41.0, 60.5 or $45.4 \%$ [21], respectively. A relatively good balance in performance has been observed for bacterial mutation assays + in vivo micronucleus assays compared to bacterial mutation assays + in vitro chromosomal aberration tests $(74.3 \% / 37.5 \%)$ [22]. The in vivo assays seem to be efficient for detecting rodent carcinogens. Additional in vivo germ cell mutagenicity assays and epidemiological studies in humans are be required to further our understanding of the effects of these substances on the health of industrial workers [23]. Before conducting genotoxicity studies, referencing the results of toxicity prediction programs, which are available for free or at a fee, along with toxicity databases and literature searches, can help determine the results of genotoxicity studies. In the present study, the results of the toxicity prediction program and the micronucleus test results did not match. These results are consistent with reports that compounds with aniline moieties, such as 4-butylanilne, are skin sensitizing chemicals and are difficult to predict toxicities [24]. Classifications were based on decision logic for germ cell mutagenicity. Therefore, it is important to recognize that previous classifications can be changed based on new test data and that classifications based on outdated or limited information are unreliable. Evaluations of test results should be verified using many sources [25]. Although the decision tree for GHS classification of germ cell mutagens is a useful tool, a totalweight-of-evidence approach is needed to provide accurate conclusions. In Korea, the GHS system has been applied to the Occupational Safety and Health Act for classification and labelling of chemicals since 2008. The weight of evidence and reliable data should be assured to ensure proper classification. In conclusion, the results obtained in the current study indicate that 4-butylaniline induces micronuclei and demonstrate that $\mathrm{N}$ butylaniline cytotoxicity via the in vivo micronucleus test.

Acknowledgments This research was funded by a grant for chemical hazard assessment from the Occupational Safety and Health Research Institute, Korea Occupational Safety and Health Agency (OSHRI, KOSHA) and the Ministry of Employment and Labor, Republic of Korea in 2018.

Conflicts of interest Authors declare no conflicts of interest with the contents of this article.

\section{References}

1. Kim CN, Roh JH, Kim TY, Phee YG, Kim KY, Park MC, Kim HS, Kim KY, Bae MJ, Cho MS (2015) A study on Industrial exposure assessment and socio-economic analysis for selection of hazardous substances to be managed. Occupational Safety and Health Research Insitute, Ulsan 
2. Rim KT, Lim CH, Ahn BJ (2015) Selection of Target Materials for GLP Genotoxic Tests by Searching the Mutagenicity Information of Chemicals by Occupational Safety and Health Act Journal of Korean Society of Occupational and Environmental Hygiene 25: 254-284

3. Kim J, Seo JK, Kim T, Kim HK, Park S, Kim PJ (2013) Prediction of Human Health and Ecotoxicity of Chemical Substances Using the OECD QSAR Application Toolbox Korean Journal of Environmental Health Sciences 39: 130-137

4. OECD Toolbox 4.2 (2018) OECD. http://www.oecd.org/chemicalsafety/ risk-assessment/oecd-qsar-toolbox.htm. Accessed 11 May 2018

5. Rim K, Kim S (2017) Mutagenicities of 4-butylaniline and $\mathrm{N}$ butylaniline determined by a bacterial reverse mutation (Ames) assay Toxicol Environ Health Sci 9: 102-107 doi:https://doi.org/10.1007/ s13530-017-0309-1

6. United Nations Economic Commission for Europe (2017) Globally Harmonized System of Classification and Labelling of Chemicals (GHS). United Nations, New York and Geneva

7. Morita T, Hayashi M, Nakajima M, Tanaka N, Tweats DJ, Morikawa K, Sofuni T (2009) Practical issues on the application of the GHS classification criteria for germ cell mutagens Regul Toxicol Pharmacol 55: 52-68 doi:10.1016/j.yrtph.2009.06.001

8. Krishna G, Hayashi M (2000) In vivo rodent micronucleus assay: protocol, conduct and data interpretation Mutat Res 455: 155-166 doi:10.1016/s0027-5107(00)00117-2

9. Kim SJ, Rim KT, Kang MG, Kim JK, Chung YH, Yang JS (2010) A Study of Micronucleus Induction with Methyl Formate and 2Methylbutane in Bone Marrow Cells of Male ICR Mice Saf Health Work 1: 80-86 doi:10.5491/SHAW.2010.1.1.80

10. OECD (2016) Test No. 474: Mammalian Erythrocyte Micronucleus Test. doi:https://doi.org/10.1787/9789264264762-en

11. Hayashi M (2016) The micronucleus test -most widely used in vivo genotoxicity test- Genes Environ 38: 18

12. Ministry of Employment and Labor (2019) Occupational Safety and Health Act. Ministry of Employment and Labor, Sejong

13. Ministry of Environment (2019) Act on the Registration and evaluation, etc. of Chemical Substances. Ministry of Environment, Sejong

14. Schmid W (1975) The micronucleus test Mutat Res 31: 9-15

15. Brueggemann LI, Sullivan JM (2002) HEK293S cells have functional retinoid processing machinery The Journal of general physiology 119:
593-612

16. Anders MW (1968) Acetone enhancement of microsomal aniline parahydroxylase activity Arch Biochem Biophys 126: 269-275 doi:10.1016/ 0003-9861(68)90583-3

17. National Center for Biotechnology Information (2019) 4-Butylaniline. PubChem Database. https://pubchem.ncbi.nlm.nih.gov/compound/4Butylaniline Accessed July 222019

18. National Center for Biotechnology Information (2019) $\mathrm{N}$-Butylaniline. PubChem Database. https://pubchem.ncbi.nlm.nih.gov/compound/ $N$ Butylaniline. Accessed July 222019

19. Chung IK, Cheon WH, Ku SK (2011) Micronucleus Test of Picrorrhiza Rhizoma Aqueous Extract in Bone Marrow Cells of Male ICR Mice Toxicol Res 27: 119-123

20. Kirkland D, Aardema M, Henderson L, Muller L (2005) Evaluation of the ability of a battery of three in vitro genotoxicity tests to discriminate rodent carcinogens and non-carcinogens I. Sensitivity, specificity and relative predictivity Mutat Res 584: 1-256 doi:10.1016/j.mrgentox.2005. 02.004

21. Morita T, Hamada S, Masumura K, Wakata A, Maniwa J, Takasawa H, Yasunaga K, Hashizume T, Honma M (2016) Evaluation of the sensitivity and specificity of in vivo erythrocyte micronucleus and transgenic rodent gene mutation tests to detect rodent carcinogens Mutat Res Genet Toxicol Environ Mutagen 802: 1-29 doi:10.1016/j.mrgentox. 2016.03.008

22. Kirkland D, Kasper P, Martus HJ, Muller L, van Benthem J, Madia F, Corvi R (2016) Updated recommended lists of genotoxic and nongenotoxic chemicals for assessment of the performance of new or improved genotoxicity tests Mutat Res Genet Toxicol Environ Mutagen 795: 7-30 doi:10.1016/j.mrgentox.2015.10.006

23. Ministry of Employment and Labor (2016) Standards for classification and labelling of chemical substances and material safety data sheets. Ministry of Employment and Labor, Sejong

24. Ouyang Q, Wang L, Mu Y, Xie X-Q (2014) Modeling skin sensitization potential of mechanistically hard-to-be-classified aniline and phenol compounds with quantum mechanistic properties BMC Pharmacology and Toxicology 15:76

25. NITE (2013) GHS Classification Guidance for the Japanese Government 3rd Ed. https://www.meti.go.jp/policy/chemical_management/int/files/ ghs/h25jgov_en.pdf. Accessed July 222019 